\title{
Technical Feasibility of the Use of Sandy Loam Soils in Concrete
}

\author{
André Conrado, Edson Miguel, Luís Cristóvão \\ Faculty of Environmental Engineering and Natural Resources, Zambeze University, Mozambique
}

\begin{abstract}
In Mozambique, the task of providing infrastructural facilities for the rapidly growing population is enormous. Although the country has unique characteristics that present opportunities for timber construction to thrive, concrete continues to be one of the most used materials in modern construction. However, the concrete industry has a considerable impact on the environment due to production and the raw material consumed. Among the constituents of concrete, sand has been the one in which its exploitation causes the most damage to the environment. An alternative to solve this problem would be the use of fine sandy loam aggregate in the production of concrete. Thus, this research presents the study of the technical feasibility of using fine sandy loam aggregate in the production of concrete. The main study variables were the consistency and mechanical strength of concrete compression. For the production of concrete, two types of gravel of $3 / 4$ were used, sandy loam soil, sandy soil and Portland cement. Specimens were manufactured for 4 different mixes, with a reference mix containing cement, sand, gravel and water. To evaluate the performance of the mixes, tests of mechanical resistance to compression were carried out at 7, 14, 21 and 28 days of age. After determining the main physical and mechanical characteristics, promising results were obtained for the mixtures with $25 \%$ and $50 \%$ substitution, where the axial compressive strength test reached $26.3 \mathrm{MPa}$ and $27 \mathrm{MPa}$, above the reference mixture of $25.6 \mathrm{MPa}$. The $100 \%$ mix of alternative soil reached an average strength of $25.2 \mathrm{MPa}$. This same mixture, although having low mechanical strength, has greater consistency, with a slump of $\pm 10 \mathrm{~cm}$.
\end{abstract}

Keywords: concrete, cement, environment, fine aggregate, mechanical strength.

DOI: $10.7176 / \mathrm{CMR} / 14-1-02$

Publication date: January $31^{\text {st }} 2022$

\section{INTRODUCTION}

Despite Mozambique being rich in tropical wood species, concrete continues to be one of the most used materials in modern construction, being composed of a mixture of water, cement and aggregates (fines and grades) resulting from the hardening of the cement paste. Over time, construction materials and methods have been continuously studied. Before, industries sought to maximize profits regardless of the damage they would cause to the environment. Recently, with population growth, economic development, urbanization and climate change, there is a growing concern in the way of production and consumption of the population. In this era of sustainable development, it is recommended that construction take place through the exploration and rational consumption of natural resources, in order to promote an ecological, social and economic vision. Concrete production negatively impacts the environment through the consumption of non-renewable resources. Among the constituents of concrete, sand has been the one in which its exploitation causes the most damage to the environment. Alternative aggregates for the production of concrete have been studied in several researches that aim to meet the environment-economysociety tripod. Thus, with the advent of sustainability, several surveys were carried out on aggregates (Sbrighi (2005), Basto (2002), Hugo (2006) and Mehta and Monteiro (2014)).

In Mozambique, there has been an improvement in housing conditions and a growing demand for construction materials, which are increasingly scarce and far from the expansion zones, a fact that has been observed in the City of Chimoio. Thus, it becomes necessary to prioritize materials and techniques that rationally use natural resources that minimize environmental degradation and at the same time reduce construction costs.

This growing demand for construction materials makes the massive exploitation of the raw material start to become scarce, a fact that happens with the fine aggregate (sand). Since most of the existing soil in the City of Chimoio is classified as sandy loam, there is a need to consider its use, as it exists in abundance in the city. Thus, it is intended with this work, and following the environmental concerns that have arisen in recent times, to take advantage of the available resource, namely fine sandy loam aggregate, and at low cost to add sandy soil, gravel and cement in a way to produce concrete by evaluating the consistency and compressive strength of concrete.

\section{MATERIAL AND METHODS}

The cement used in the research was Portland cement, B-L $32.5 \mathrm{~N}$, which is characterized by the addition of pozzolan in a content ranging from $15 \%$ to $50 \%$ by mass. The fine aggregate used in the traces comes from Vanduzi district. From the aggregate, about $50 \mathrm{~kg}$ of sample were extracted, used later in the tests to characterize the aggregate and the remainder for the manufacture of concrete. 


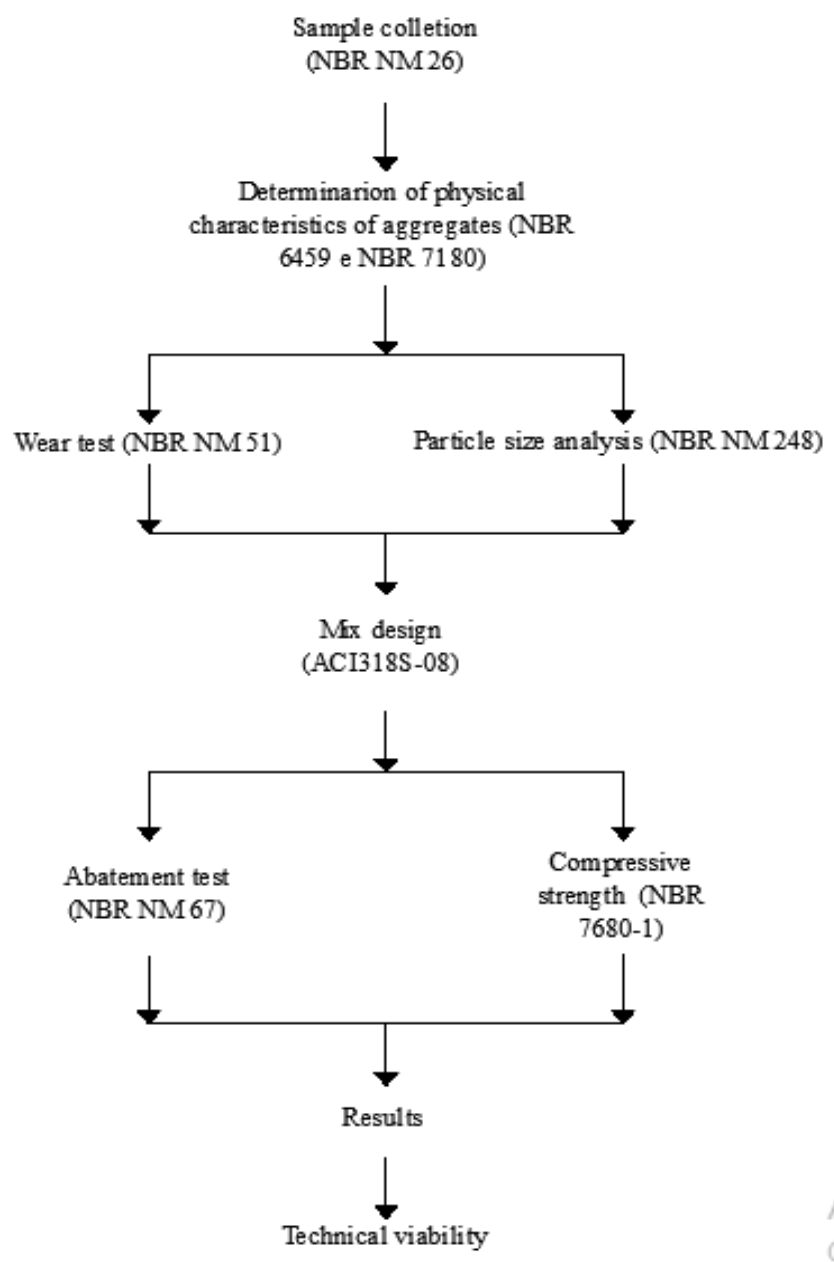

Figure 1: Methodology and technical standards

The soil sample used in the mixtures as an alternative fine aggregate was extracted at the Zambezi-Chimoio University Campus, where about $25 \mathrm{~kg}$ of sample were collected. The sample was dried in the patio at room temperature and exposed to the sun, where it was submitted to a physical-mechanical characterization test.

Gravel 1 comes from the province of Manica - Chiremera, where about $50 \mathrm{~kg}$ of gravel $3 / 4$ were collected. The choice of the quarry for sample collection is justified by presenting a production process with greater specificity and control. This quarry is the only one that produces coarse aggregate, having in its production process a washing step that minimizes the amount of powdery material, differentiating its material from other crushing quarries existing in Manica Province.

Gravel 2 comes from Manica Province, municipality of Chimoio - Vila Nova, where around $50 \mathrm{~kg}$ of sample were extracted. This quarry produces large quantities of coarse aggregate sold in the city, even though it does not have a quality control, the gravel from this quarry is derived from igneous rocks that are fragmented into fractions very close to $3 / 4$. The flowchart of the processes performed is shown in Figure 1.

\section{Sample Preparation}

After extracting the soil samples, the following procedures were carried out: A certain amount of soil was dried in the open air, this quantity being greater than that which would be used to prepare the specimens and in the characterization tests. The clods were dismantled and then the material was carefully homogenized. To have a representative sample of the material, quartering was used, reaching a mass of $6.25 \mathrm{~kg}$ in order to carry out the granulometry tests, Atterberg limits, wear test. The remaining material was used for molding the specimens, Figure 2 . 


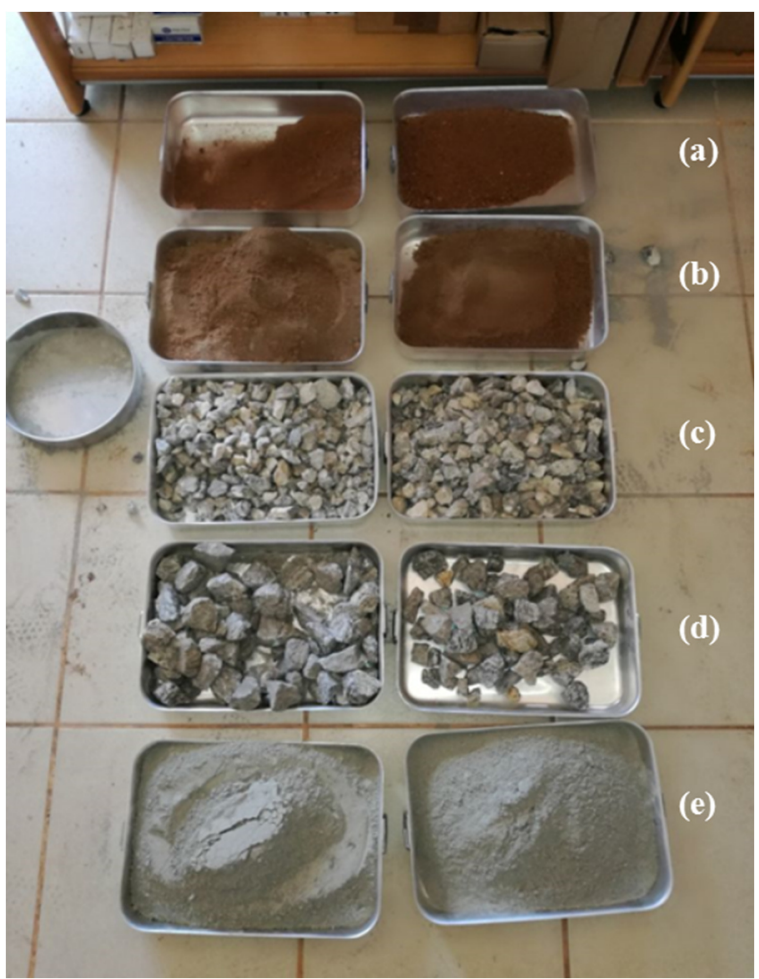

Figure 2: Materials used for the production of concrete: (a) sandy loam soil (b); sandy soil; (c); gravel 1; (d) gravel 2 (e) Portland cement.

In the tests, technical standards were applied according to Figure 1. The compressive strength test was performed using a hydraulic press, Figure 3.
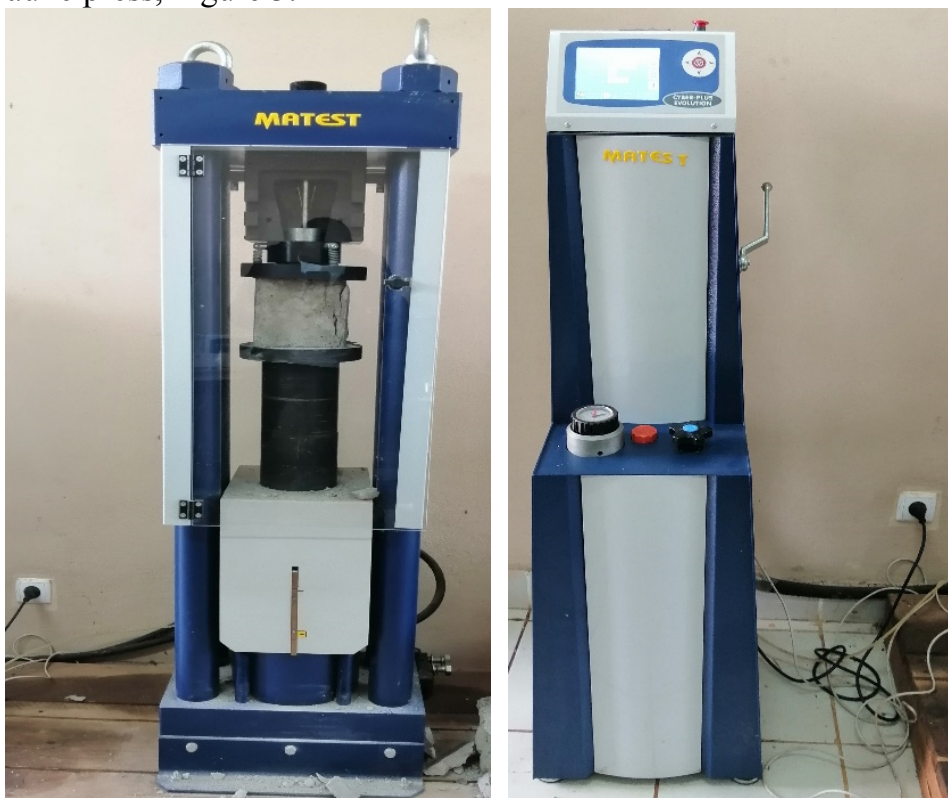

Figure 3: Hydraulic press used in the compressive strength test

\section{RESULTS AND DISCUSSION}

\subsection{Determination of physical characteristics}

Table 1 illustrates the results of the physical characterization of the samples - granulometry and Atterberg limits.

Table 1: Physical characterization of materials

\begin{tabular}{|c|c|c|c|c|c|}
\hline MG $_{\text {SA }}$ & MG $_{\text {SFA }}$ & MG $_{\text {B1 }}$ & MG $_{\text {B2 }}$ & LL & LP \\
\hline 1.67 & 1.71 & 3.00 & 2.94 & 38.0 & 33.3 \\
\hline
\end{tabular}

Analyzing the granulometry tests carried out with the fine aggregates, the soil samples with the presence of quartz particles, with the presence of iron oxide and small particles of silt and clay can be called optimal particle size because their fineness modules are in the range from 1.00 to 3.00 according to the NBR NM 248 standard. 
However, the soil with the presence of iron oxide "reddish soil" has a very fine fraction passing through the 0.15 $\mathrm{mm}$ sieve. In this case, the soil is classified as clayey soil, taking into account that the liquidity limit value found of $38 \%$ is less than $40 \%$ and the plasticity index is less than $10 \%$ according to the NBR6459 e NBR7180 standard.

\subsection{Concrete consistency}

Table 2 shows the results of the consistency of the concrete made with different mixes 1:2:3 (Cement, sand and gravel) where the defined percentage was being substituted for mixtures of $25 \%, 50 \%$ and $100 \%$, obtaining the following values of slump for each mix.

Table 2: Concrete consistency

\begin{tabular}{|l|c|}
\hline \multicolumn{1}{|c|}{ Concrete traces } & Rebate $(\mathrm{cm})$ \\
\hline Real trace & 14 \\
\hline Trace $25 \%$ & 13 \\
\hline Trace $50 \%$ & 11 \\
\hline Trace $100 \%$ & 10 \\
\hline
\end{tabular}

The trunk slumping results showed that the samples meet the tolerances required by the NBR NM 67 standard, which governs a maximum slump of $15 \mathrm{~cm}$. The dosage with $100 \%$ of alternative fine aggregate showed less slump, which may be related to the higher level of thin material in the mixture, which interferes with the consistency of the concrete. The tests show increased workability in concrete with the replacement of the rolled sand fraction from white colored basaltic rocks by reddish colored sand. During the execution of the tests, it was verified that the dosages with reddish soil incorporated in the mixture presented greater cohesion and less tendency to segregation, this due to the presence of silt and clay determined through the soil granulometric test. This presence ends up working as binders, thus increasing the percentage of binders in the mixture. According to Neville and Brooks (2013), they state that the volume of voids is directly proportional to the consumption of cement. Figure 4 illustrates the slump test.

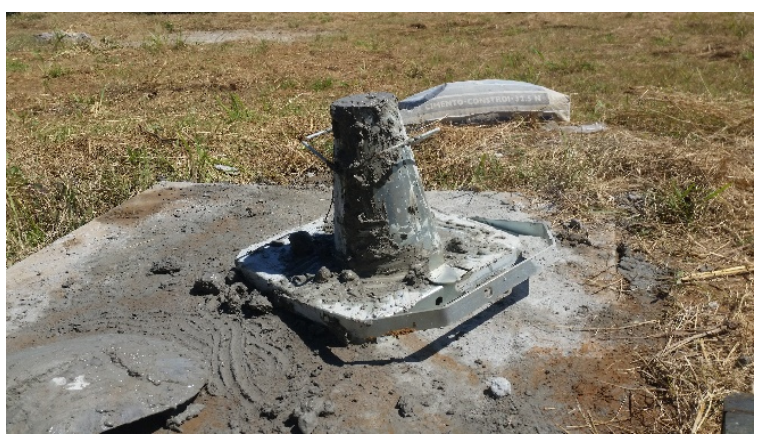

Figure 4: Concrete consistency

\subsection{Compressive strength evaluation}

During the axial compressive strength tests, it was found that the samples with partial replacements present better technical performance compared to the reference mixture, Figure 5.

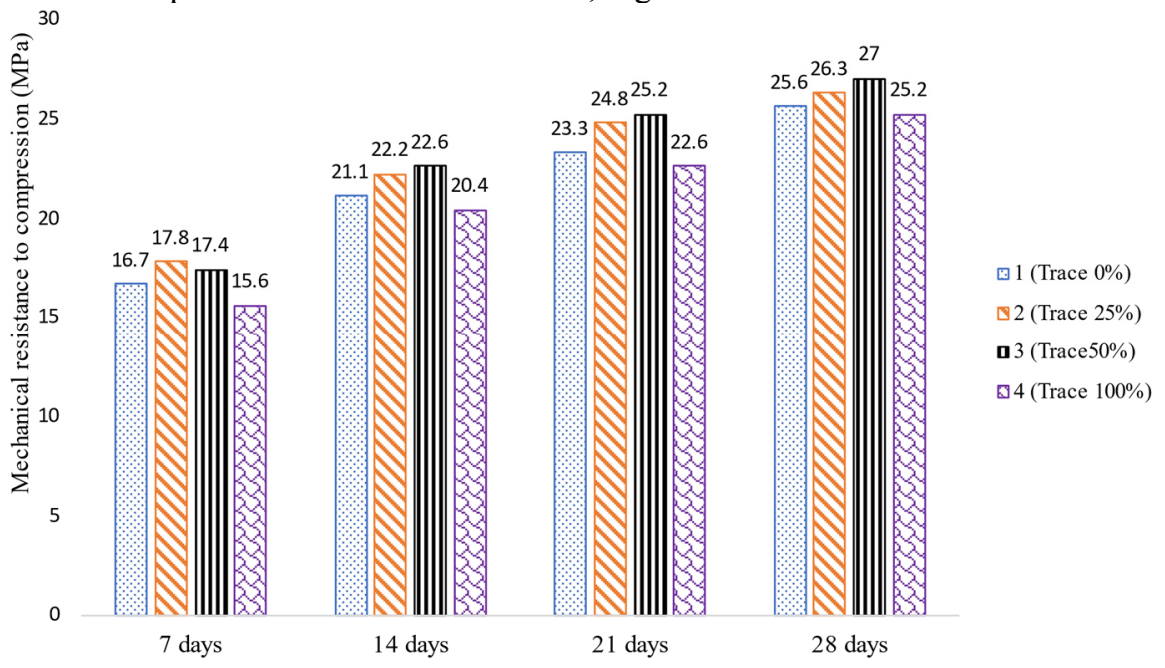

Figure 5: Mechanical resistance to compression

From the study, it was found that the mixture with the 50\% replacement obtained a final strength of 27.00 $\mathrm{MPa}$, the maximum value obtained in tests followed by the replacement at $25 \%$ with an average strength of 26.30 
MPa. These values are higher than those presented by the reference mixture, which obtained a final strength of the order of $25.80 \mathrm{MPa}$. A possible explanation for these results is that the sandy loam soil has a percentage of clay and silt decreasing the void index and creating larger contact surfaces, which is directly proportional to the mechanical strength. These results show the feasibility of replacing the natural coarse aggregate by $25 \%$ and $50 \%$ fine aggregate with the presence of silt and clay, which is indicated with the presence of iron oxide leaving a reddish soil. The blend with the $100 \%$ replacement had an average final strength of $25.20 \mathrm{MPa}$ above the default blend of $25.00 \mathrm{MPa}$. Again, the result proves the feasibility of partially replacing the white natural fine aggregate by reddish natural fine aggregate.

\section{CONCLUSION}

For all mixtures made in this study, it was possible to conclude that:

1. Mechanical strength increased with time. Analyzing the results individually, we can affirm that all the mixes presented axial compressive strength, superior to the concrete compressive strength predicted for the age of " 28 " days, which was determined to be $25.00 \mathrm{MPa}$.

2. The replacement of fine sandy aggregate by fine sandy loam aggregate in the production of concrete demonstrated technical feasibility, as well as environmental sustainability, as the compressive strengths achieved were higher than the agreed values.

3. The material found in Manica Province can be used to replace fine sandy aggregate without high technical losses, thus reducing the cost of transport for the preparation of concrete, especially in rural areas.

\section{ACKNOWLEDGEMENTS}

The authors express their gratitude to the Ministry of Science Technology and Higher Education for providing financial support through the Production of quality cement blocks at low-cost project.

\section{REFERENCES}

1. BASTOS, Sandra Regina Bertocini. Uso da areia artificial basáltica em substituição parcial à areia fina para produção de concreto convencional. Florianópolis: UFSC, 2002 . Disponível em $:<$ https://repositorio.ufsc.br/xmlui/bitstream/handle/123456789/84274/212200.pdf?sequence=1\&isAllo wed $=\mathrm{y}>$. Retrieved: 31 Maio 2021

2. LODI, Victor Hugo. Viabilidade técnica e econômica do uso de areia de britagem em concretos de cimento portland na região de Chapecó - SC. Dissertação (Pós-Graduação) Universidade Federal de Santa Catarina convênio Unochapecó, Programa de Pós-Graduação em Engenharia Civil, Florianópolis, 2006. Available: $<$ http://www.basalto.eng.br/dissertacao vhl vs final.pdf $>$.

3. MEHTA, P. Kumar; MONTEIRO, Paulo J. M. Concreto: microestrutura, propriedade e materiais. 2. Ed. São Paulo. IBRACON, 2014

4. NBR NM 26: Agregados - Amostragem, 2001.

5. $\quad$ NBR 6459: Determinação do Limite de Liquidez, 2016.

6. $\quad$ NBR 7180: Determinação do Limite de Plasticidade, 2016.

7. NBR NM 51: Agregado graúdo - Ensaio de Abrasão "Los Angels", 2001.

8. NBR NM 248: Agregados - Determinação da composição granulométrica, 2003.

9. NBR NM 67: Concreto: Determinação da consistência pelo abatimento do tronco do cone, 1998.

10. NBR 7680-1: Concreto - Extração, preparo, ensaio e analise de testemunhos de estruturas de concreto. Parte 1: Resistência a Compressão Axial, 2015.

11. NEVILLE, A. M.; BROOK CCFMV NSJ. J. Tecnologia do concreto. 2. Ed. Porto Alegre. Bookman, 2013

12. SBRIGHI NETO, Cláudio, “A Importância dos Conceitos Tecnológicos na Seleção dos Agregados para Argamassas e Concretos”. Revista Areia \& Brita. EMC-Editores; nº 12; 1999. 